\title{
Determinants of financial performance of listed firms manufacturing food products in Vietnam: regression analysis and Blinder-Oaxaca decomposition analysis
}

Determinants of financial performance

\author{
Nhung Le Thi Kim
}

Faculty of Finance and Banking, Thuongmai University, Hanoi, Vietnam

Daphné Duvernay

Toulon University, La Garde, France, and

Huyen Le Thanh

Faculty of Finance and Banking, Thuongmai University, Hanoi, Vietnam

\begin{abstract}
Purpose - This article studies the impact of micro and macro factors on firm performance in the context of an emerging economy just changed from a subsidized economy to a market economy.

Design/methodology/approach - The authors carried out an investigation into 30 listed food processing companies in Vietnam from 2014 to 2019. The data are analyzed by using STATA software. In this study, beside the regression analytical technique, theBlinder-Oaxaca decomposition analysis is used to study more deeply the effect of variables on financial performance of food processing companies, so its results are reliable base to give suggestions. Findings - The results of empirical research help us to have some following conclusion. First, two variables consisting of total assets turnover ratio (ATR) and growth in sales significantly influence financial performance, when it is measured by return on equity (ROE) or return on sales (ROS). Second, leverage significantly negatively impacts return on sale. Third, there are difference in financial performance and the effect of predictors on dependent variable "ROS" between state-owned enterprises (SOEs) and non SOEs, and the causes come from the component effect.

Originality/value - In fact, although a range of previous researches on that topic have been carried out, none of them dig deeper reasons resulting to the differences in financial performance between SOEs and non SOEs, whereas Vietnamese economy has just changed to a market economy since 1986, making impacts of State ownership totally different from other countries. In this study, the authors use the $t$-test and analysis to have more accurate conclusions about that problem.
\end{abstract}

Keywords Firms manufacturing food products, Regression analysis, Blinder-Oaxaca decomposition analysis Paper type Research paper

\section{Introduction}

Always does the high financial performance draw main attention from every manager, because it plays a vital position within the structure and development of a firm, however, that aim is often challenged by many factors, leading to a low level of firm performance. Studying

(C) Nhung Le Thi Kim, Daphné Duvernay and Huyen Le Thanh. Published in Journal of Economics and Development. Published by Emerald Publishing Limited. This article is published under the Creative Commons Attribution (CC BY 4.0) licence. Anyone may reproduce, distribute, translate and create derivative works of this article (for both commercial and non-commercial purposes), subject to full attribution to the original publication and authors. The full terms of this licence may be seen at http:// creativecommons.org/licences/by/4.0/legalcode
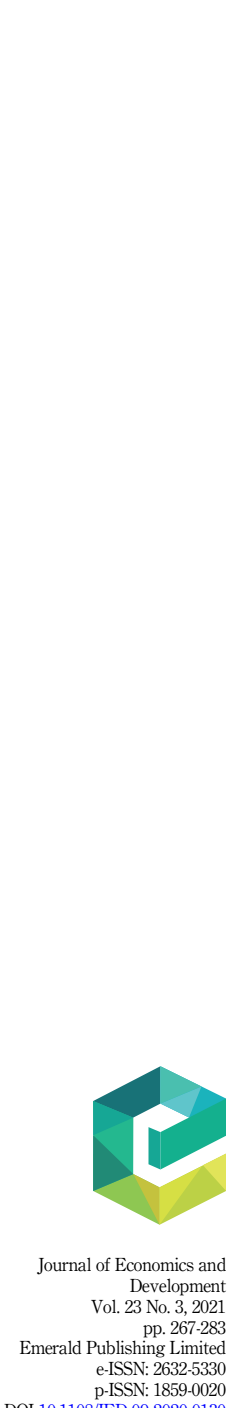
JED

23,3

268

determinants of financial performance is getting necessary to companies in Vietnam, especially food processing firms, because their business results are not good, meanwhile, there are a lot of advantages of macro economy and many priorities given to them. In addition, the influence of State ownership needs to be studied more carefully, because the Vietnamese economy has just changed from a subsidized economy to a market economy since 1986, making the impact of state ownership totally different from other countries. Actually, a range of researches on that topic have been carried out, but none of them dig deeper reasons resulting to the differences in financial performance between state-owned enterprises (SOEs) and non SOEs. In our study, beside focusing on the impact of some micro and macro factor on firm financial performance in food processing industry, we use the $t$-test and Blinder-Oaxaca analysis to assess the impact of State ownership on the companies, helping us to have more accurate conclusions about the impact of factors in research model and get a more reliable basis for proposing solutions for food manufacturing companies.

\section{Literature review and hypothesis development}

\subsection{Financial performance}

Firm financial performance is used as a tool measuring an organization current development and potential growth. Although there are many indicators estimating financial performance, the choice of appropriate ratios depends on the characteristics of studied objects and study purposes. In studies, ROE and ROS are two of the most used ratios to measure financial performance (Walsh, 1987). For example, Waddock and Graves (1997) used ROA, ROE and ROS to measure the company's financial performance, whereas Ruf et al. (2001) selected ROE, ROS and growth in sales in the study of the determinants of financial performance. Margarita (2004) has measured financial performance based on ROA, ROE and ROS to study the relationship between social responsibility and corporate financial performance. Mara and Nicoleta (2019) used ROE to evaluate financial performance of studied companies. Many researchers agree that the use of those financial ratios give them valuable information of firm financial performance. While ROE shows the efficiency of equity, ROS reflects the effectiveness of the company's cost management. In other words, one ratio refers the capacity to use the capital (input of capital), the other refers to the ability to manage the operating cost (output of capital). Therefore, the use of these two financial indicators will help researchers to have more comprehensive conclusions about the financial performance of enterprises.

\subsection{State ownership}

Relating to this matter, some researchers spend attention on the influence of the existing state ownership on financial performance. Although there are a lot of researches on that issue, the conclusion of its influence is still argued. On the one hand, some researchers agree that state ownership is considered as a "helping hand" that could provide an abundance of capital, thereby improve firm financial performance. On the other hand, many people describe it as "grabbing hand" which assumes that firm's profit could be more extracted to some politician purposes (Tian and Estrin, 2008). Theoretically, in the property rights perspective in economics (Martin and Parker, 1997; Villalonga, 2000) and the residual claimant theory (Rowthorn and Chang, 1993), economists indicate the public ownership inefficiency. Empirically, Jiang et al. (2013) show that for SOEs firm, their characteristics can predict external successions, but for non SOEs. Qi et al. (2000) indicate that the performance of public SOEs firms could be influenced by the ownership structure and relative control by either the state or legal-person shareholdings. Sun et al. (2002) prove that a concave N-shape can reflect the relationship between government ownership and firm performance in both highly state controlled firms and very low state owned or privatized firms.

H1. State ownership influences firm financial performance. 


\subsection{Quick ratio}

According to Van Horne and Wachowicz (2005), ratios measuring liquidity is a tool to help analysts determine the company's ability to fulfill short-term financial obligations. Owolabiand Obida (2012) indicate that "liquidity" has a crucial position in the success of a firm, because the failure to meet its obligation in due time could lead to a low credit rating by the creditors, decrease in the value of growth in the market and finally a reduction in capacity to have more capital in the future. Meanwhile, the capital is the core of a good financial performance. Therefore, factor of liquidity plays an important role in working capital management (Sanna and Sandra, 2009), and the influence of has to be carefully considered. Many researchers such as Adams and Buckle (2003), Fazzari et al. (1988), Hu and Michael (2006), Zahra and Azam (2012), Victor et al. (2013) found the significant positive influence of liquidity on financial performance.

There is a rage of financial ratios to measure the corporate liquidity, and the choice of appropriate ratio depends on the characteristics of studied objects. For companies having a large amount of short-term debt like food processing firms, the quick ratio $(\mathrm{QR})$ is commonly used. The study of Seema et al. (2011) increase in QR brought a strong impact on financial performance.

\section{H2. Quick ratio influences firm financial performance.}

\subsection{Total assets turnover ratio}

According to Stephen et al. (2010), this ratio helps managers know how efficient they are in using company assets to generate sales. Theatrically, a high total assets turnover partly shows some potential developments of a company relating to increasing its sales, expanding its market share, finally, improving its financial performance. Empirically, Wu and Zhu (2010) analyze empirically the factors affecting business performance of listed agricultural enterprises. Research results show a significant positive relationship between the ratio of financial performance and total asset turnover of firms. Seema et al. (2011) evaluates corporate performance by using total asset turnover, long-term asset turnover and short-term asset turnover. The authors point out that low turnover is a sign of ineffective use of available resources and that the company has not fully exploited its capacity or assets. Similarly, Dinh and Sha (2011) use total asset turnover to evaluate business results of enterprises. Analysts conclude that the higher the efficiency of assets use, the better the company's operating efficiency.

\section{H3. Total assets turnover ratio influences firm financial performance.}

\subsection{Leverage}

Leverage indicates the level of the debt. It is directly related to the capital used in a company, so it is an issue interested by many people like managers, shareholders, investors, creditors. Therefore, there have been researches carried out to identify the influence of that variable on financial performance of a company, but there is not the final conclusion to that problem. Some researchers such as Asimakopoulos et al. (2009) and Al-Jafari and Samman (2015) found that leverage is negatively correlated to financial performance; the reason is that high debt requires more resources to pay the debt. However, others like Burja (2011), Humera et al. (2011) argue that additional debt can be implemented in a good investment, which will increase financial performance.

\section{H4. Leverage influences firm financial performance.}

\subsection{Firm size}

Firm size could influence its financial performance in many ways. A larger company could more affect its current and potential investors, creditors, its stakeholders, even its consumers. 
JED

23,3

That is proved by the high business performance of conglomerates and multinational corporations in global economy. As a consequence, firm size is considered as a determinant of financial performance by many researchers. However, there are various result of the effect between firm size and financial performance. Stierwald (2009), Vijayakumar (2011), Ayele (2012), Erasmus (2013) found a positive influences between firm size and financial performance. While Dhawan (2001), Ramasamy (2005), Salman and Yazdanfar (2012) found that firm size have a negative effect to the financial performance.

H5. A firm's size influences its financial performance.

\subsection{Growth in sales}

According Deitiana (2011), high growth in sales is one of signs of a firm business success in the past, and it could be used as a tool to predict the development in the future. It partly shows that the capacity of the company to expand the market share or launch new products. In addition, that good ratio also helps the firm to interest more investors. Therefore, there have been also numerous researches in the influence of that variable on firm financial performance, and many of them like studies done by Krishnan and Moyer (1997), Zeitun and Tian (2007), Liu (2010) and Yazdanfar (2013) found a positive and significant relationship between firm growth and performance.

H6. Growth in sales influences firm financial performance.

\subsection{Consumer price index}

In this study, the consumer price index $(\mathrm{CPI})$ is selected to represent the group of macro factors, because one of characteristics of food processing industry is to be strongly influenced by the change in price and inflation. Although there have been a range of researches on the influence of this factor on firm financial performance, their finding is different from each other. The studies of Demirguc-Kunt and Maksimovic (1999), Booth et al. (2001) show that the increase of CPI can lead to the decrease of the use of debt in enterprises, and reducing the degree of debt is able to make the company's business performance increased. Meanwhile, Deng et al. (2009), point out that as the CPI increases, companies will find that many of the benefits of using financial leverage diminish, which makes many managers hesitate to use debt to finance your business.

H7. Consumer price index influences firm financial performance.

\section{Data and methodology \\ 3.1 Variables measurement (see Table 1)}

\subsection{Data}

The study is analytical in nature and involved testing of hypotheses quantitatively. The main content of this research approach is to find out a concise answer to the research questions through the collection and analysis of information of firms. In order to evaluate the influence of independent variables on financial performance of food processing companies, thirty listed Vietnamese companies manufacturing food products are selected. For the purpose of completing research goals, dataset has to meet some requirements including: 30 selected companies must have been in business before 2014; there is no disruption in their business operation; dataset has both SMEs and non-SMEs. The study is mainly based on secondary financial data including income statements, balance sheets and cash flow statements for period of 2014-2019. This offered an improved understanding of the links existing among the variables. 


\begin{tabular}{|c|c|c|c|}
\hline Variable & Measurement & Scale & Determinants \\
\hline \multicolumn{4}{|l|}{ Dependent variable $(Y)$} \\
\hline ROE & Net income & Ratio & \\
\hline \multirow{2}{*}{ ROS } & $\begin{array}{l}\text { Average Shareholder's Equity } \\
\text { Operating profit }\end{array}$ & Ratio & \\
\hline & Net sales & & \\
\hline \multirow{2}{*}{$\begin{array}{l}\text { Independent variables }(X) \\
\text { Quick ratio }(\mathrm{QR})\end{array}$} & & & 27 \\
\hline & $\begin{array}{l}\text { Current assets-Inventory } \\
\text { Current liabilities }\end{array}$ & Ratio & \\
\hline \multirow[t]{2}{*}{ Total assets turnover ratio (ATR) } & Sales & Ratio & \\
\hline & Total assets & & \\
\hline \multirow[t]{2}{*}{ Leverage (LEV) } & Total liabilities & Ratio & \\
\hline & Total assets & & \\
\hline Firm size (Size) & Log of Total Assets & Ratio & \\
\hline \multirow[t]{2}{*}{ Growth in sales (GROWTH) } & $\left(\right.$ Sales $_{t}-$ Sales $\left._{t-1}\right)$ & Ratio & \\
\hline & Sales $_{t-1}$ & & Table 1. \\
\hline CPI & Consumer price index & Ratio & Variables \\
\hline
\end{tabular}

\subsection{Research method}

3.3.1 Empirical model of estimation. My basic panel model is in the form:

$$
Y_{i t}=\beta_{0}+\beta_{i} X_{i, t}+\mu_{i, t}
$$

where $\beta_{0}$ is a constant, $X_{i, t}$ is a $\mathrm{K}$-dimensional vector of explanatory variables and $\mu_{i, t}$ is the error term which is further decomposed into the following disturbance terms:

$$
\mu_{i, t}=\alpha_{i}+\varepsilon_{i, t}
$$

Where $\alpha_{i}$ is individual firm effects and it is constant over the time and $\varepsilon_{i, t}$ is error.

Following the works of. ... with modifications, we modeled our study as follows:

$$
\begin{aligned}
\text { Model 1 }: & \mathrm{ROE}_{i, t} \\
= & \beta_{0}+\beta_{1} \mathrm{QR}+\beta_{2} \mathrm{ATR}_{i, t}+\beta_{3} \mathrm{LEV}_{i, t}+\beta_{4} \mathrm{GROWTH}_{i, t}+\beta_{5} \mathrm{Size}_{i, t}+\beta_{6} \mathrm{CPI}_{i, t}+\alpha_{i} \\
& +\varepsilon_{i, t}
\end{aligned}
$$

Model $2: \operatorname{ROS}_{i, t}$

$$
\begin{aligned}
= & \beta_{0}+\beta_{1} \mathrm{QR}+\beta_{2} \mathrm{ATR}_{i, t}+\beta_{3} \mathrm{LEV}_{i, t}+\beta_{4} \mathrm{GROWTH}_{i, t}+\beta_{5} \mathrm{Size}_{i, t}+\beta_{6} \mathrm{CPI}_{i, t}+\alpha_{i} \\
& +\varepsilon_{i, t}
\end{aligned}
$$

Where: ROS is return on sales, ROE is return on equity, $\mathrm{QR}$ is quick ratio, ATR is total assets turnover ratio, LEV is leverage, GROWTH is growth in sales, Size is firm size and CPI is consumer price index, and $\varepsilon$ is error.

3.3.2 Research method. Data processing technique include calculating data analysis model, which is assisted by STATA version 14. In this research, the regression analytical technique is used to find out the influence of firm determinants on financial performance. In addition, the Blinder-Oaxaca decomposition analysis is carried out to study the causes of the difference in financial performance between SMEs and non-SMEs, thereby, its results are reliable base to give suggestions. First, we use the $t$-test to assess the impact of state 
JED

23,3

272

ownership on the companies, if the results show that there is difference in financial performance of SOEs and non SOEs, Oaxaca-Blinder decomposition analysis is necessary and meaningful. Second, we determine the fit model (Chow test, Breusch and Pagan Lagrangian multiplier test and Hausman test are used to help us to choose appropriate model for research sample). Third, the Wald test and Wooldridge test are used to check the existence of heteroskedasticity and the autocorrelation problem, if there are both issues, the Cluster regression will be carried out. On the other hand, if only the heteroskedasticity exists, robust standard error estimation will be used. Finally, if there is a difference in financial performance between the two groups of food processing companies, we will use decomposition analysis techniques to find causes of the difference.

\section{Empirical results}

\subsection{Panel unit root test}

In order to test the stationariness of the data, first, panel unit root test was carried out. When time series do not have unit roots or they are stationary, results generated from such series normally tend to be better and hence do not lead to inconsistent outcomes. There are a number of unit root panel tests (Harris and Tzavalis, 1999; Im et al., 2003 and Levin et al., 2002), and the Levin-Lin-Chu test was chosen to examine whether our series are contain unit root. The null hypothesis is that the series contain a unit root and the alternative is that the series is stationary.

From our results as presented in Table 2 , it is realized that eight variables including ROE, ROS, QR, total ATR, leverage (LEV), firm size (Size), growth in sale (GROWTH) and CPI are stationary at level hence have no unit roots. Thus, we obtain all our series to be stationary as we reject the null hypotheses that the series are non-stationary.

\subsection{Descriptive statistics}

With the data from the financial statements of listed companies manufacturing food products in Vietnam, some ratios are calculated

Table 2 shows that the average ROE of the surveyed companies is $12.85 \%$. Although that result is greater than 0 , according to many researchers, a company's ROE should be at least $15 \%$ to ensure the company's financial capacity and helps it become more interesting to investors. Meanwhile, their financial ratio of mean ROS is $5.1 \%$, it is an acceptable result, but in a period of strong growth of the economy, that level is expected to be at least $10 \%$, so it is not appreciated, especially when the food processing industry has received a lot of priorities from the Government and it is considered as the spearhead economic sector. In addition, there is a big gap between lowest and highest value, revealing the large difference in financial performance among firms. On the other hand, remaining financials ratios demonstrated

Table 2.

\begin{tabular}{lcccccr}
\hline Variable & Obs & Mean & Std. Dev. & Min & Max & Status \\
\hline ROE & 180 & 0.1285131 & 0.0879535 & 0.0021463 & 0.3059481 & Level \\
ROS & 180 & 0.0513967 & 0.0436983 & 0.0006982 & 0.1527116 & Level \\
QR & 180 & 1.213155 & 0.8356104 & 0.2893399 & 3.220861 & Level \\
ATR & 180 & 1.558767 & 0.845108 & 0.5343837 & 3.608985 & Level \\
LEV & 180 & 0.4798448 & 0.1965424 & 0.119112 & 0.7776923 & Level \\
Size & 180 & 27.56639 & 1.205318 & 25.69325 & 29.81456 & Level \\
GROWTH & 180 & 0.1028449 & 0.260647 & -0.2648557 & 0.8169564 & Level \\
CPI & 180 & 0.0287267 & 0.0111354 & 0.0063 & 0.0408 & Level \\
\multicolumn{2}{l}{ Note(s): (Result from Stata 14) } & & & & \\
\end{tabular}


partly their operations that enormously different from each other. Based on those numbers, we can first conclude that the business performance of some companies in the food processing industry in Vietnam is not appreciated between 2014 and 2019, despite the fact that the economy of Vietnam developed rather well in the studied period with the gross domestic products rate rising from $3.78 \%$ to $9.58 \%$ [1]. In other words, there were firms that did not take advantage of the development of the economy, indicating a need of finding out factors impacting on financial performance of listed Vietnamese food processing companies and demand of reasonable measures suggested in order to improve their business results.
Determinants of financial performance

\subsection{Correlation analysis}

Table 3 shows the strength and direction of the relationship between variables which is examined. Correlation is significant at the 0.05 level between the ROS on one side and QR, total ATR, leverage, firm size and growth in sale on the other side. On the other hand, there is also significant correlation between ROE and some variables including total ATR, leverage and growth in sales.

\subsection{Checking for multicollinearity}

Table 4 shows that there is a perfect linear relationship between firm size and leverage. The measure used in the article is to remove the variable "Size" from our model.

According to the results (Table 5), after variable "Size" removed, it can be concluded that there is no multicollinearity problem in this model.

\subsection{Result of $\mathrm{t}$-test}

In the 1st model, the result calculated by Stata 14 shows that $\operatorname{Pr}(|T|>|t|)$ is equal 0.1810 , so the null hypothesis is accepted. In other words, the financial performance (measured by ROE) of SOEs and non SOEs is the same with each other, and the Oaxaca-Blinder decomposition analysis is not necessary.

Meanwhile, in the 2nd model, the value of $\operatorname{Pr}(|T|>|t|)$ calculated by Stata 14 is equal 0.0015 , so the null hypothesis is rejected, it means that there is difference in financial performance (measured by ROS) between two groups of companies, and the Oaxaca-Blinder decomposition analysis is necessary and meaningful.

As can be seen from Table 6, mean ROS of SOEs is lower than that of non SOEs, revealing the higher financial performance of companies in group 1 .

\subsection{Discussion of regression results}

4.6.1 Model 1. First, the decision whether to use the simple ordinary least square (OLS) or fixed effect panel data regression is based on the Chow test. The results show that fixed effect is appropriate for surveyed enterprises, because the $p$-value (0.0000) is less than 0.05. Second, the result of Breusch and Pagan Lagrangian multiplier test shows that the $p$-value is 0.0000 , so random effect panel data regression is more suitable for research sample than OLS. Third, the selection of one model from random effect and fixed effect options is based on the Hausman test. The Hausman test result for 30 listed Vietnamese food processing companies indicates the use of random effect model is better because $p$-value is more than 0.05 . On the other hand, the Wald test indicates that there is the heteroskedasticity problem in the model and Wooldridge test shows the existence of autocorrelation in panel data, so Cluster regression is used to solve those problems. Based on the results reported in Table 7, two independent variables significantly influencing the financial performance of companies are total ATR and growth in sales, and both their impact is positive. 
JED

23,3

274

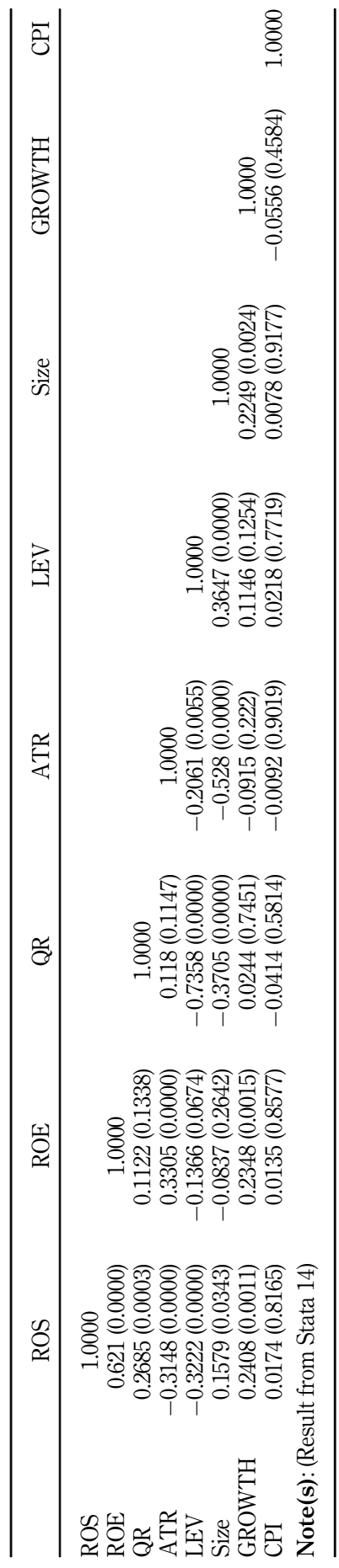

Table 3.

Correlation matrix 


\begin{tabular}{|c|c|c|c|c|c|}
\hline \multirow{2}{*}{ Variable } & \multicolumn{2}{|c|}{ ROS } & \multicolumn{2}{|c|}{ ROE } & \multirow{2}{*}{$\begin{array}{l}\text { Determinants } \\
\text { of financial }\end{array}$} \\
\hline & VIF & $1 / \mathrm{VIF}$ & VIF & $1 / \mathrm{VIF}$ & \\
\hline Size & 38.84 & 0.025749 & 38.84 & 0.025749 & madice \\
\hline LEV & 15.91 & 0.062853 & 15.91 & 0.062853 & \\
\hline CPI & 7.68 & 0.130283 & 7.68 & 0.130283 & \\
\hline $\mathrm{QR}$ & 6.29 & 0.159053 & 6.29 & 0.159053 & \\
\hline ATR & 4.24 & 0.235797 & 4.24 & 0.235797 & 275 \\
\hline GROWTH & 1.21 & 0.827725 & 1.21 & 0.827725 & \\
\hline Mean VIF & 12.36 & & 12.36 & & Table 4. \\
\hline Note(s): (I & a 14) & & & & VIF result \\
\hline
\end{tabular}

\begin{tabular}{|c|c|c|c|c|}
\hline \multirow[b]{2}{*}{ Variable } & \multicolumn{2}{|c|}{ ROS } & \multicolumn{2}{|c|}{ ROE } \\
\hline & VIF & $1 / \mathrm{VIF}$ & VIF & $1 / \mathrm{VIF}$ \\
\hline CPI & 6.46 & 0.154786 & 6.46 & 0.154786 \\
\hline LEV & 4.91 & 0.203861 & 4.91 & 0.203861 \\
\hline ATR & 3.92 & 0.254983 & 3.92 & 0.254983 \\
\hline QR & 3.04 & 0.328739 & 3.04 & 0.328739 \\
\hline GROWTH & 1.21 & 0.827733 & 1.21 & 0.827733 \\
\hline Mean VIF & 3.91 & & 3.91 & \\
\hline
\end{tabular}

Note(s): (Result from Stata 14)

Table 5.

VIF result after removing variable "Size"

\begin{tabular}{lccccc}
\hline Group & Mean & Std. Err. & Std. Dev. & {$[95 \%$ Conf. } & Interval \\
\hline 0 & 0.0592052 & 0.0044033 & 0.0470149 & 0.0504814 & 0.0679291 \\
1 & 0.0379091 & 0.0041272 & 0.0335296 & 0.0296665 & 0.0461517 \\
combined & 0.0513967 & 0.0032571 & 0.0436983 & 0.0449695 & 0.0578239 \\
diff & 0.0212961 & 0.0065872 & & 0.008297 & 0.0342952
\end{tabular}

Note(s): (Result from Stata 14), Group 1: Non SOEs, Group 2: SOEs

Table 6. $T$-test result for ROS

4.6.2 Model 2. 4.6.2.1 Result of regression for whole research sample. Similar to the 1st model, in the 2nd model, the results of Chow test, Breusch and Pagan Lagrangian multiplier test and Hausman tests indicate that random effect regression is appropriate to the research sample. The Wald test and Wooldridge test also shows the existence of heteroskedasticity and the autocorrelation problem, so Cluster regression is used to give us more exact results. Based on numbers in Table 8, we can conclude that when the financial performance is measured by ROS, it is significantly affected by three predictors including total ATR, leverage and growth in sales. While ATR and LEV negatively impact the dependent variable at the 0.01 level, the variable "GROWTH" positively influences financial ratio ROS at the 0.1 level.

4.6.2.2 Result of regression for two groups of companies. The results reported in Table 9 shows a lot of differences between two groups companies. For sample of non SOEs, a series of tests lead to the fact that random effect regression is the most suitable, but both heteroskedasticity and the autocorrelation problem exist. According to the result of Cluster regression, there are two variables that significantly negatively impact the financial performance of the group 1 at the 0.01 level, including total ATR. Meanwhile, it is fixed effect regression that is the most appropriate for sample of SOEs, and there is only heteroskedasticity problem in this model. However, the result of robust Standard errors 
JED
23,3

276

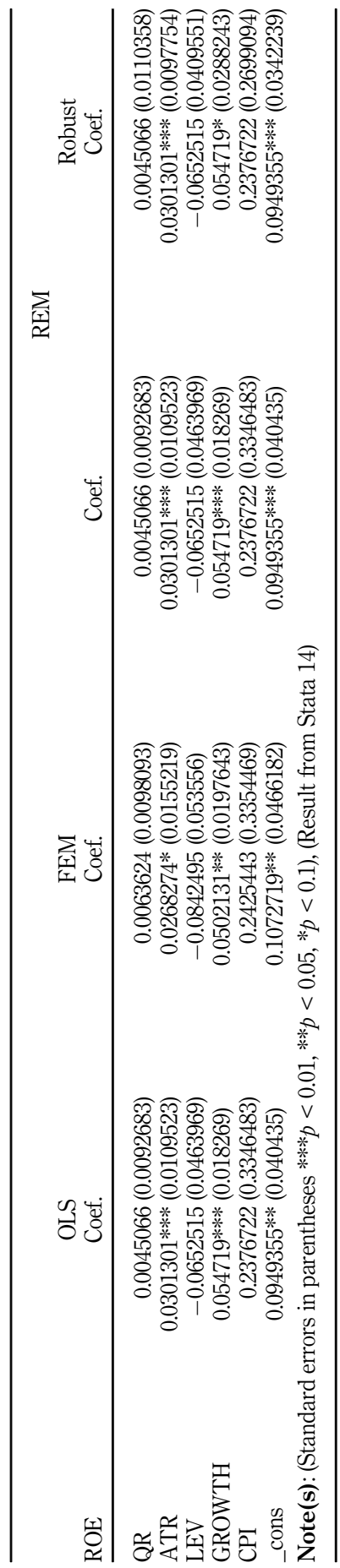

Table 7.

Regression results 


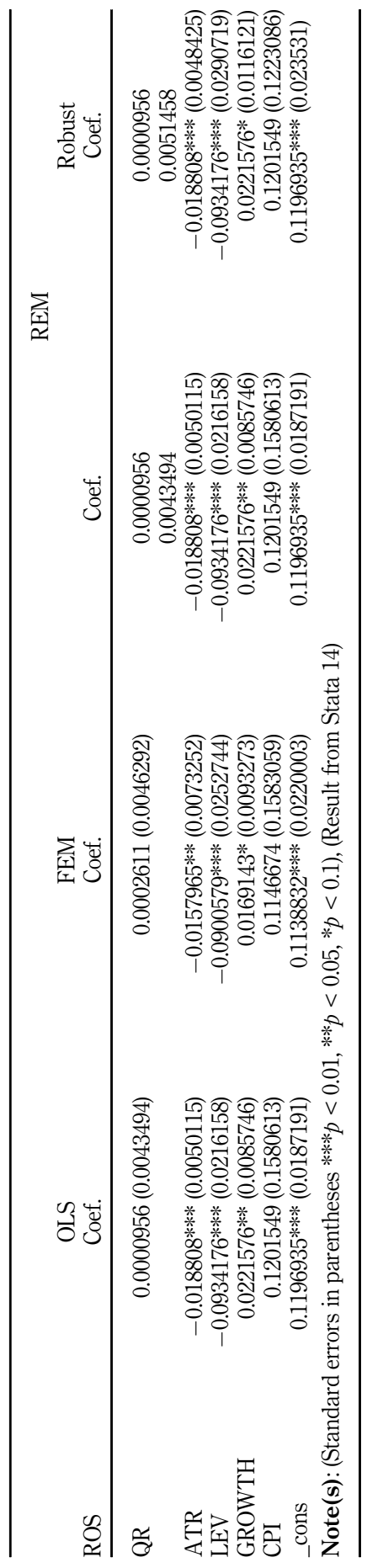

Determinants of financial performance

277

Table 8. Regression results 
JED
23,3

278

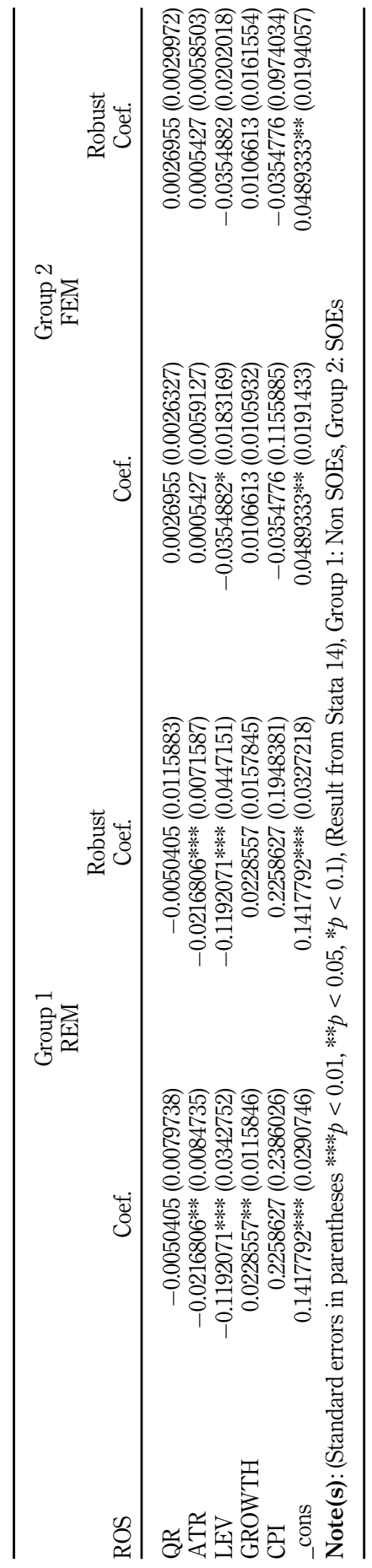

Table 9.
Regression results

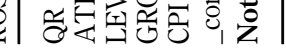


estimation indicates that there is not any predictor significantly influencing the financial performance of the group 2.

4.6.2.3 Blinder-Oaxaca decomposition analysis. In order to study the difference in financial performance and the effect of micro and macro variables on financial performance between SOEs and non SOEs, we conduct decomposition analysis. This method was first built and developed by Blinder (1973) and Oaxaca (1973) with the aim of finding out why race and sex lead to wage gap between groups. Later, it was used in other research areas including corporate finance. In that analytical technique, the difference of the comparing groups is separated into two components:

(1) The first one called "explained" or "Component effect" is caused by the differences in average observable characteristics of the individuals;

(2) The second part called "unexplained" or "Structure effect" is not the result of group differences in the predictors, it is usually attributed to discrimination.

In this study, not only is the total decomposition of the outcome differential into an explained and an unexplained part, but also the detailed contributions of the single predictors are subject to investigation.

The results reported in Table 10 show that the difference between the two groups is mainly explained by the composition effect, of which three variables including ATR, LEV and GROWTH contribute significantly to the difference. However, their coefficient also indicates that it is the variable "ATR" that could create largest gap between group 1 and group 2. Meanwhile, regarding unexplained component, only predictor "QR" significantly affects the difference in financial performance of non SOEs and SOEs.
Determinants of financial performance

\begin{tabular}{lccc}
\hline & & Robust & Std. Err. \\
ROS & Coef. & & $p$-value \\
\hline Differential & & 0.0043979 & 0.0000 \\
Group_1 & 0.0592052 & 0.0041187 & 0.0000 \\
Group_2 & 0.0379091 & 0.0060253 & 0.0000 \\
Difference & 0.0212961 & & 0.8420 \\
Explained & & 0.0010592 & 0.0000 \\
QR & 0.000211 & 0.0037324 & 0.0130 \\
ATR & 0.0179952 & 0.0036208 & 0.0100 \\
LEV & -0.0090144 & 0.0021232 & 1.0000 \\
GROWTH & 0.0054453 & 0.0002507 & 0.003 \\
CPI & $-5.03 E-19$ & 0.0049752 & \\
Total & 0.0146371 & & 0.0940 \\
Unexplained & & 0.0121285 & 0.8340 \\
QR & & 0.011267 & 0.2580 \\
ATR & -0.0202942 & 0.0177301 & 0.2370 \\
LEV & -0.0023594 & 0.0012648 & 0.3010 \\
GROWTH & -0.0200372 & 0.0103061 & 0.2370 \\
CPI & -0.0014945 & 0.0339565 & 0.261 \\
Cons & 0.0106685 & 0.0059188 &
\end{tabular}

Note(s): (Result from Stata 14), Group 1: Non SOEs, Group 2: SOEs

The variables in italics are the variables that cause the significant difference in financial performance between the two groups of companies

Table 10.

Blinder-Oaxaca decomposition 
JED

23,3

280

\section{Discussion and conclusion}

Companies manufacturing food products play an important role in the Vietnamese economy, but the financial performance of firms in this industry is not as high as the expectation, therefore, studying determinants of their financial performance is a necessary activity. By using the data of 30 listed food processing companies in Vietnam, we have some following conclusions

First, two variables consisting of total ATR and growth in sales significantly influence financial performance when it is measured by ROE or ROS. However, while GROWTH influences positively both ROE and ROS, the impact of ATR on ROE is in contrast to that on ROS. Those results are reasonable for companies manufacturing food products. For that industry, solutions to increase growth in sale are used by numerous leaders, because the profit on each product is rather low, so increasing sales can help companies ensure their financial performance. In addition, consumers are affected a lot by their buying habits, therefore, managers often want to capture the largest market share as soon as possible to avoid huge costs and losses in the future. Regarding the impact of ATR, its negative effect on ROS can be understood due to the economic nature of these two financial ratios, whereas its positive influence on ROE reveals a fact that for food processing companies, the efficiency of the use of capital is able to change the ROE. In fact, it is a big effort of these firms in the studied period, due to the erratic weather from 2014 to 2019, raw material prices were not stable, and one of their characteristics is their preference for short-term debt, resulting to difficulties on controlling many kinds of costs. Though, these obstacles did not seem to be difficult to them, and the increase in ATR still leads to ROE enhanced. However, empirical results evoke following point, depending on the goals of company, measures for ATR should be be carefully considered. If the finance director pursues the goal of improving capital efficiency, policies to increase ATR should be applied. By contrast, if the company wants to show that it is highly effective to increase sales to capture market share, solutions to decrease that ratio could be more appropriate.

Second, leverage significantly negatively impacts return on sale of firm, so when leaders want to enhance ROS, controlling the use of debt could minimize the financial cost and help them to reach their business aim. The effect of leverage can be explained by their misuse of debt. Due to the short production cycle of food products, many businesses depend heavily on debt, leading to high financial costs, which is particularly not beneficial during a period of many fluctuations in raw material prices and interest.

Third, there are differences in financial performance and the effect of predictors on dependent variable "ROS" between SOEs and non SOEs, the financial performance of companies in group 1 (non SOEs) is higher than that of group 2 (SOEs). In fact, the result is reasonable, because until now, the management activities of SOEs, especially in the financial sector have not been good, and bureaucratic and subsidized ideology still exists in the leadership, leading to an negative impact on business performance. While ATR and LEV have the significant impact on financial performance of companies in the group 1, no predictor in the model significantly influences that performance of companies in the group 2. The causes that are identified by decomposition analysis come from the component effect, where variables including ATR, LEV and GROWTH contribute significantly to this difference. As a result, depending on the level of State ownership of each firm, managers should consider suitable solutions to improve its financial performance.

\section{Note}

1. Data of World Bank 


\section{References}

Adams, M. and Buckle, M. (2003), "The determinants of corporate financial performance in the Bermuda insurance market”, Applied Financial Economics, Vol. 13 No. 2, pp. 133-143.

Al-Jafari, M.K. and Al Samman, H. (2015), "Determinants of profitability: evidence from industrial companies listed on Muscat Securities Market", Review of European Studies, Vol. 7 No. 11, pp. 303-311.

Asimakopoulos, I., Samitas, A. and Papadogonas, T. (2009), "Firm-specific and economy wide determinants of firm profitability-Greek evidence using panel data”, Managerial Finance, Vol. 35 No. 11, pp. 929-940.

Ayele, G.A. (2012), Factors Affecting Profitability of Insurance Companies in Ethiopia: Panel Evidence, Addis Ababa University, Ethiopia.

Blinder, A.S. (1973), "Wage discrimination reduced form and structural estimates", Journal of Human Resources, Vol. 8 No. 4, pp. 436-455.

Booth, L., Aivazian, V., Demirguc-Kunt, A. and Maksimovic, V. (2001), "Capital structures in developing countries", Journal of Finance, Vol. 56, pp. 87-130.

Burja, C. (2011), "Factors influencing the company's profitability", Annales Universitatis Apulensis Series Oeconomica, Vol. 13 No. 2, pp. 215-224.

Deitiana, T. (2011), "The effect of financial ratios, sales growth and dividends is limited stock prices", Journal of Business and Accounting, Vol. 13 No. 1, pp. 57-65.

Demirguc-Kunt, A. and Maksimovic, V. (1999), "Institutions, financial markets, and firm debt maturity", Journal of Finance Economics, Vol. 54, pp. 295-336.

Deng, L. and Luo, H. (2009), "An empirical study of the macroeconomic factors that affect the capital structure of agricultural listed companies", Journal of Market Modernization, Vol. 11, pp. 28-29.

Ding, H. and Sha, R. (2011), "Empirical analysis of the impact of capital structure on performance in Jilin Forest Industry Co., Ltd”, Issues of Forestry Economics, Vol. 31 No. 2, pp. 141-144.

Dhawan, R. (2011), "Firm size and productivity differential: theory and evidence from a panel of US firms", Journal of Economic Behaviour and Organization, Vol. 44, pp. 269-293.

Erasmus, F.K. (2013), "Impact of size and age on firm performance: evidence from microfinance institutions in Tanzania”, Research Journal of Finance and Accounting, Vol. 4 No. 5, pp. 105-116.

Fazzari, E.F. and Jensen, M. (1988), "Separation of ownership and control", Journal of Law and Economics, Vol. 26 No. 6, pp. 74-98.

Harris, R.D.F. and Tzavalis, E. (1999), "Inference for unit roots in dynamic panels where the time dimension is fixed", Journal of Econometrics, Vol. 91, pp. 201-226.

$\mathrm{Hu}, \mathrm{R}$. and Michael, A. (2006), "Antecedents and performance outcomes of diversification: a review and critique of theoretical perspectives", Journal of Management, Vol. 16, pp. 461-509.

Humera, K., Maryam, M., Khalid, Z., Sundas, S. and Bilal, S. (2011), "Corporate governance and firm performance: case study of karachi stock market", International Journal of Trade Economic and Finance, Vol. 2, pp. 39-43.

Im, K.S., Pesaran, M.H. and Shin, Y. (2003), "Testing for unit roots in heterogeneous panels”, Journal of Econometrics, Vol. 115, pp. 53-74.

Jiang, F., Huang, J. and Kim, K.A. (2013), "Appointments of outsiders as CEOs, state-owned enterprises, and firm performance: evidence from China", Pacific-Basin Finance Journal, Vol. 23, pp. 49-64.

Krishnan, V.S. and Moyer, R.C. (1997), "Performance, capital structure and home country: an analysis of Asian countries”, Global Finance Journal, Vol. 8 No. 1, pp. 129-143.

Levin, A., Lin, C.F. and Chu, C.S.J. (2002), "Unit root tests in panel data: asymptotic and finite-sample properties", Journal of Econometrics, Vol. 108, pp. 1-24.

Liu, Q. (2010), "Establishing a model of firm financial performance evaluation", Accounting and Auditing, Vol. 6, pp. 249-250.

Determinants of financial performance

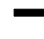


JED

23,3

282

Mara, M. and Nicoleta, B.M. (2019), "The financial performance of European companies: explanatory factors in the context of Economic Crisis", Ekinomika, Vol. 98 No. 2, pp. 6-18.

Margarita, T. (2004), "Corporate social responsibility and financial performance", Working Paper Series, University of California, Berkeley.

Martin, S. and Parker, D. (1997), The Impact of Privatisation: Ownership and Corporate Performance in the UK, Routledge, London.

Oaxaca, R.L. (1973), "Male-female wage differentials in urban labor markets", International Economic Review, Vol. 9, pp. 693-709.

Owolabi, S.A. and Obida, S.S. (2012), "Liquidity management and corporate profitability: case study of selected manufacturing companies listed on the Nigerian stock exchange", Business Management Dynamics, Vol. 2 No. 2, pp.10-25.

Qi, D., Wu, W. and Zhang, H. (2000), "Shareholding structure and corporate performance of partially privatized firms: evidence from listed Chinese companies”, Pacific Basin Finance Journal, Vol. 8 No. 5, pp. 587-610.

Ramasamy, B. (2005), "Firm size, ownership and performance in the Malaysian palm oil industry", Asian Academy of Management Journal of Accounting and Finance, Vol. 1, pp. 81-104.

Rowthorn, B. and Chang, H.J. (1993), Public Ownership and the Theory of the State, The Political Economy of Privatisation, Routledge, London, pp. 54-69.

Ruf, B.M., Muralidhar, K., Brown, R.M., Janey, J.J. and Paul, K. (2001), “An empirical investigation of the relathionship between change in corporate social performance and financial performance: a stakeholder theory perspective", Journal of Business Ethics, Vol. 32, pp. 143-156.

Salman, A.K. and Yazdanfar, D. (2012), "Profitability in Swedish SME firms: a quantile regression approach", International Business Research, Vol. 5 No. 80, pp. 94-106.

Sanna, L. and Sandra, V. (2009), "Impact of liquidity management on profitability. A study of the adaptation of liquidity strategies in a financial crisis", Master thesis, UMEA School Business, UMEA University.

Seema, G., Jain, P.K. and Yadav, S.S. (2011), "Impact of MoU on financial performance of public sector enterprises in India", Journal of Advances in Management Research, Vol. 8 No. 2, pp. 263-284.

Stephen, A.R., Randolph, W.W. and Bradford, D.J. (2010), Fundamentals of Corporate Finance, McGraw-Hill, New York, NY.

Stierwald, A. (2009), "Determinants of firm profitability-the effect of productivity and its persistence", in Melbourne Institute of Applied Economic and Social Research, The University of Melbourne.

Sun, Q., Tong, H.S. and Tong, J. (2002), "How does government ownership affect firm performance? Evidence from China's privatization experience", Journal of Business Finance and Accounting, Vol. 29, pp. 1-27.

Tian, L. and Estrin, S. (2008), "Retained state shareholding in Chinese Plcs: does government ownership always reduce corporate value?", Journal of Comparative Economics, Vol. 36, pp. $74-89$.

Van Horne, J.C. and Wachowicz, J.M. Jr (2005), Fundamentals of Financial Management, Prentice Hall: Financial Times.

Victor, C.L., Samuel, A. and Eric, K.B. (2013), "The relationship between liquidity and profitability of listed banks in Ghana", International Journal of Business and Social Sciences, Vol. 14 No. 3, pp. 48-56.

Vijayakumar, A. (2011), "The determinant of profitability: an empirical investigation using Indian automobile industry", International Journal of Research in Commerce and Management, Vol. 2 No. 1, pp. 58-64.

Villalonga, B. (2000), "Privatization and efficiency: differentiating ownership effects from political, organizational, and dynamic effects", Journal of Economic Behavior and Organization, Vol. 24 No. 1, pp. 43-74. 
Waddock, S.A. and Graves, S.B. (1997), "The corporate social performance- financial performance link", Strategic Management Journal, Vol. 18 No. 4, pp. 303-319.

Walsh, F.J. (1987), "Measuring business unit performance", National Industrial Conference Board Research Bulletin, No. 206.

$\mathrm{Wu}$, J. and $\mathrm{Zhu}, \mathrm{M}$. (2010), "Empirical analysis of rural influencing factors on listed agribusiness financial performance", Agricultural Economics and Management, Vol. 3, pp. 22-27.

Yazdanfar, D. (2013), "Profitability determinants among micro firms: evidence from Swedish data", International Journal of Managerial Finance, Vol. 9 No. 2, pp. 150-160.

Zahra, M. and Azam, J. (2012), "The relationship between working capital management and firm performance. Evidence from Iran”, International Journal of Humanities and Social Science, Vol. 2 No. 2, pp. 141-146.

Zeitun, R. and Tian, G.G. (2007), "Capital structure and corporate performance: evidence from Jordan”, Australasian Accounting, Business and Finance Journal, Vol. 1 No. 4, pp. 40-61.

\section{Further reading}

Coban, S. (2014), "The interaction between firm growth and profitability: evidence from Turkish (listed) manufacturing firms", Bilgi Economisi ve Yoneimi Dergisi, Vol. 9 No. 2, pp. 73-82.

Goddard, J., Tabakoli, M. and Wilson, J. (2005), "Determinants of profitability in European manufacturing and services: evidence from a dynamic panel model”, Applied Financial Economics, Vol. 15 No. 18, pp. 1269-1289.

$\mathrm{Hu}, \mathrm{R}$. and Michael, A. (2006), "Antecedents and performance outcomes of diversification: a review and critique of theoretical perspectives", Journal of Management, Vol. 16, pp. 461-509.

Jensen, M.C. and Murphy, K.J. (1990), "Performance pay and top-management incentives", Journal of Political Economy, Vol. 98 No. 1, pp. 225-264.

McDonald, J. (1999), "The determinants of firm profitability in Australian manufacturing”, The Economic Record, Vol. 75 No. 229, pp. 115-26.

Qian, L. (2010), "Establishing a model of firm financial performance evaluation", Accounting and Auditing, Vol. 6, pp. 249-250.

Ross, S.A., Westerfield, R. and Jordan, B. (2010), Fundamentals of Corporate Finance, McGraw-Hill, New York, NY.

Stierwald, A. (2010), "The causes of profit heterogeneity in large Australian firms", Working Paper, No. 7/10, University of Melbourne, Melbourne Institute of Applied Economic and Social Research, Melbourne.

Titman, S. and Wessels, R. (1988), “The determinants of capital structure choice”, Journal of Finance, Vol. 43, pp. 1-19.

Vijayakumar, A. (2011), "An empirical study of firm structure and profitability relationship: the case of Indian automobile firms", International Journal of Research in Commerce and Management, Vol. 1 No. 2, pp. 100-108.

Whited, T. (1992), "Debt, liquidity constraints and corporate investment: evidence from panel data", Journal of Finance, Vol. 47, pp. 1425-1460.

\section{Corresponding author}

Huyen Le Thanh can be contacted at: lethanhhuyen@tmu.edu.vn

For instructions on how to order reprints of this article, please visit our website:

www.emeraldgrouppublishing.com/licensing/reprints.htm

Or contact us for further details: permissions@emeraldinsight.com
Determinants of financial performance 